\title{
Un modello HBIM per la catalogazione dei restauri e la gestione degli interventi: la Rocca estense di San Martino in Rio
}

\author{
Luca Masiello \\ Daniela Oreni \\ Mauro Severi
}

Abstract

\begin{abstract}
Gli studi e le analisi condotte sulla Rocca estense di San Martino in Rio, un piccolo borgo nella provincia di Reggio Emilia, si sono focalizzati sugli interventi di restauro e riuso condotti sull'edificio dagli anni settanta del Novecento ad oggi, dallo studio d'architettura Severi. Scopo della ricerca è stato quello di esplorare la possibilità di creare un modello tridimensionale BIM dell'edificio nel quale far confluire tutti i dati, prevalentemente cartacei (disegni, relazioni, computi metrici, ecc.), all'interno di un unico ambiente tridimensionale digitale, in modo da poter interrogare bilateralmente il database lavori a partire dal modello o dalle informazioni organizzate in campi. É stato pertanto necessario procedere con una esplorazione dell'archivio cartaceo esistente, inventariato, per poi organizzare i dati e digitalizzare i documenti esistenti. Tale fase è risultata fondamentale anche per decidere come rappresentare e scomporre il modello 3D dell'edificio nei suoi diversi elementi architettonici, in modo da poter associare nella maniera più diretta possibile tutte le informazioni disponibili, relative ai diversi interventi di conservazione, consolidamento e restauro avvenuti nel tempo.

Lo scopo ultimo di questo progetto di ricerca è stato quello di creare uno strumento digitale che potesse servire per le future attività di conservazione dell'edificio e per la gestione delle attività di manutenzione programmata del bene, essendo aperto ed implementabile.
\end{abstract}

Parole chiave

catalogazione, archivio, rilievo, conservazione, HBIM.

Progetto di ampliamento e fortificazione di San Martino in Rio, 1556 c Archivio di Stato di Modena.

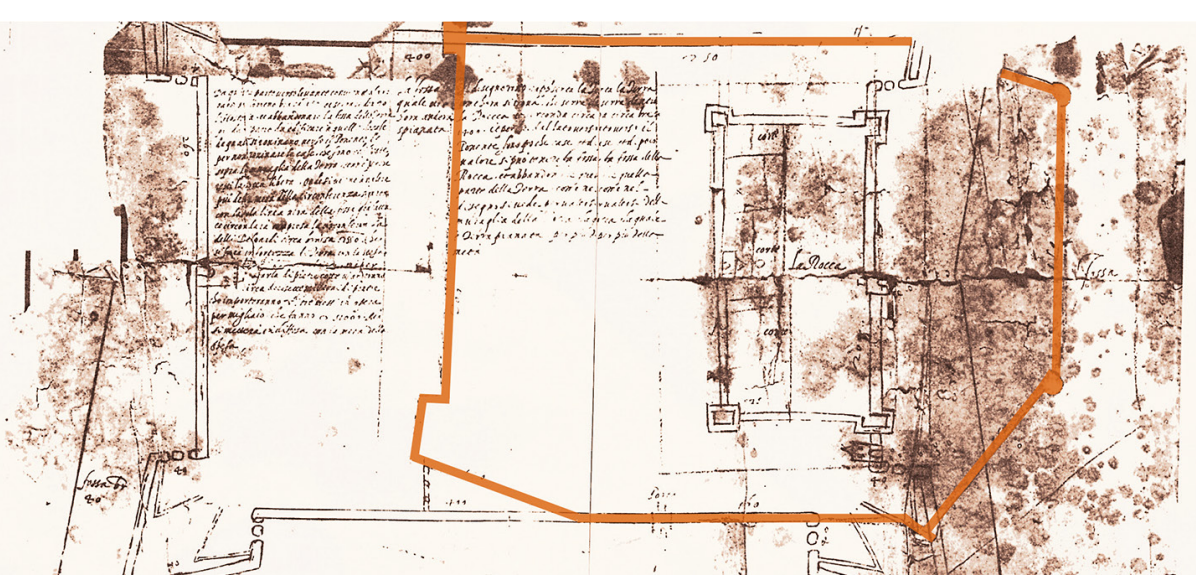




\section{La Rocca di San Martino in Rio nella storia: trasformazione e restauri}

La più antica testimonianza dell'esistenza in questo luogo di un edificio fortificato risale al Mille [Severi 2003] (fig. I). Nell'elenco dei castelli e delle pievi ricevute in feudo da Bonifacio di Canossa (985-1052) dai Vescovi reggiani, viene infatti citato il Castellum Sancti Martini in Rio. Al I I I5 corrisponde una crescita di importanza del sistema difensivo sammartinese, infeudato alla famiglia dei Roberti.

Dopo il I343, l'edificio è nuovamente fortificato diventando cardine difensivo del territorio nelle lotte per la creazione delle Signorie emiliane. Quando la famiglia dei Roberti passa dall'alleanza con i Gonzaga a quella con i Visconti, la Rocca subisce una devastazione e ricostruzione nel 1353.

Nel 1442 dopo il consolidamento della Signoria Estense, Leonello d'Este, Signore di Ferrara, Reggio e Modena, dona al fratello Borso il feudo di San Martino in Rio e Campogalliano come bene personale. Borso inizia opere di sistemazione della Rocca, per adeguarla a sua residenza: oltre ad una ristrutturazione generale è restaurata l'ala nord e costruito un porticato con colonne in marmo nell'ala est. L'edificio è oggetto di un programma di decorazione ad opera dei pittori della famiglia modenese degli Erri; le varie imprese di Borso ritrovate durante i restauri appartengono a questo periodo di interventi. Nel I490 il centro di San Martino è affidato come feudo o Signoria autonoma a Sigismondo d'Este, fratello di Borso, e inizia così la Signoria degli Estensi detti di San Martino, ramo cadetto che si estinguerà nel 1752.

Nel 1557 la Rocca viene nuovamente assediata ed espugnata e vengono danneggiate le mura e le parti fortificate dell'edificio.

È Filippo d'Este, nuovo Signore e marchese, che in occasione delle sue nozze con Maria, figlia di Emanuele Filiberto di Savoia, interviene con importanti lavori di ampliamento e sistemazione interna, a partire dal 1570, con l'aggiunta di nuove sale, dello scalone nell'ala ovest, e con la creazione di nuovi apparati decorativi. Questi lavori sono attribuiti all'architetto Giovan Battista Aleotti.

Un'importante campagna di restauri della Rocca è nuovamente condotta a partire dal I 772 , per volere del nuovo feudatario di don Paolo Rango d'Aragona; tutto l'edificio è adeguato negli spazi e negli apparati decorativi al gusto dell'epoca. Un salone viene trasformato in teatro, le stanze sono decorate con stucchi, camini in scagliola e marmo, i soffitti lignei del $\mathrm{XVI}$ secolo sono ridipinti o ricoperti con cannucciati, arellature. Nella facciata dell'ala est sono aperte nuove finestre mentre la facciata principale è decorata dal pittore modenese Bosellini. Dal I813 la Rocca è acquistata dalla Comunità e trasformata per ospitare uffici, magazzini e residenze private. Continuano le manomissioni e gli utilizzi incongrui.
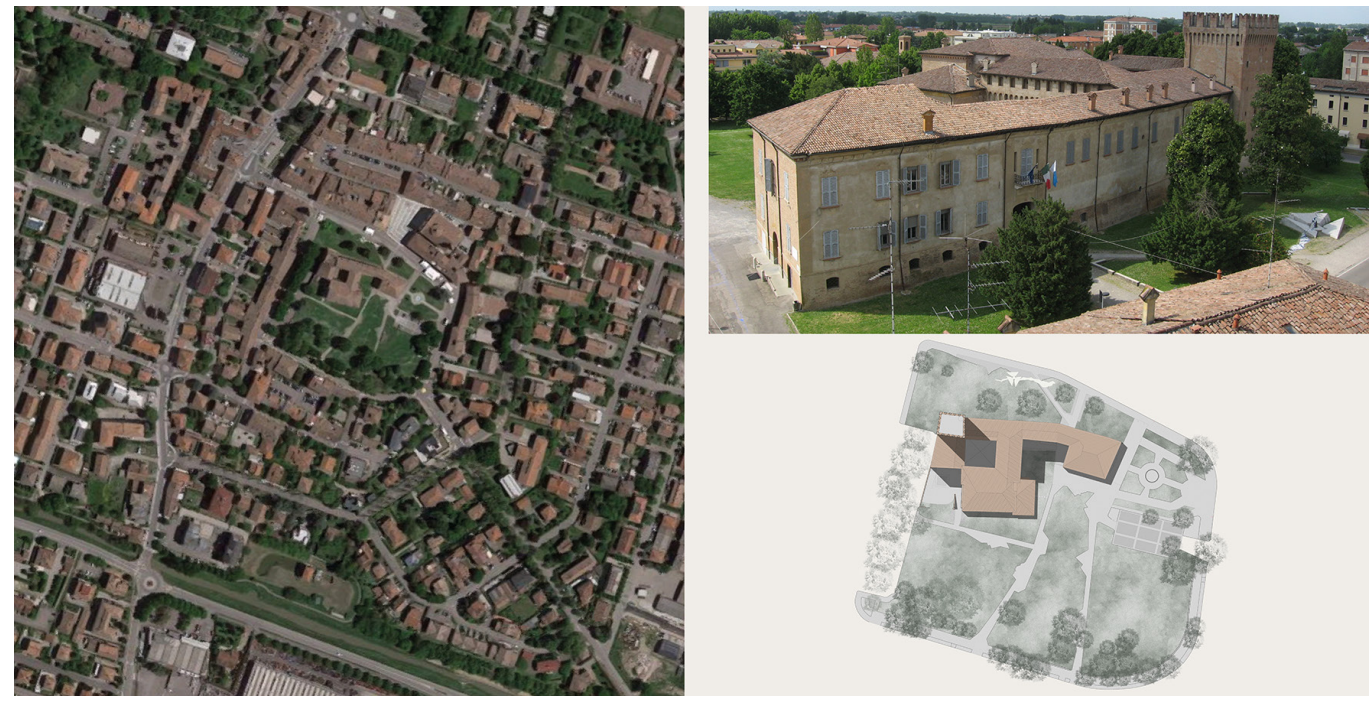
Fig. 2. In alto, gli stemm proprimiglie nobill, proprietarie della Rocca nel corso dei secoli, significative degli elementi significative degli elementi architettonici riferibili ai lavori realizzati dai diversi proprietar
Fig. 3. I diversi colori indicano i vari lotti di restauro che sono stati condotti sull'edifcio dalo condio studio Severi, a partire Novecento ad oggi.

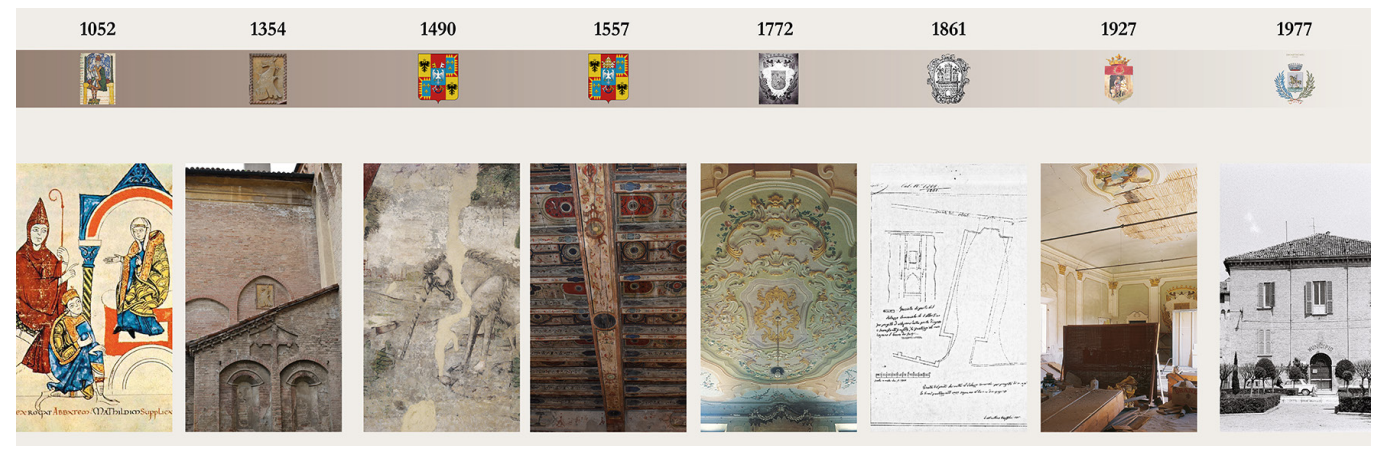

Nel 1927 sono ritrovati i soffitti dipinti con fasce e grottesche delle due sale al di sopra del portico est. Dopo due anni, è rimossa la copertura del Torrazzo nell'intento di un improbabile ripristino medioevale.

Nel 1972 iniziano i rilievi dell'intero edificio e, nel 1977, il comune approva il progetto generale di restauro e recupero della Rocca Estense, redatto dagli architetti Mauro Severi e Gianfranco Varini (fig. 2); nello stesso anno vengono autorizzati anche gli interventi di consolidamento e revisione del tetto della cappella di San Giovanni.

Il cantiere di restauro prende avvio nel 1980 con il consolidamento delle fondazioni dell'ala nord, proseguendo con il restauro e la sistemazione del piano nobile dell'ala est, dell'ala tra i due cortili, e dei pavimenti in cotto del XVIII secolo, nel piano nobile dell'ala est. Nel 1987 inizia prima il restauro della facciata est, quindi quello della cappella di San Giovanni. Nel 1994 viene riaperto il museo dell'agricoltura. Dal 1997 vengono eseguiti lavori di ripristino e consolidamento delle coperture, dei sottotetti e dei solai lignei, a seguito dei danni provocati dal sisma. Gli ultimi interventi riguardano le riparazioni dei danni provocati dal terremoto del 2012.

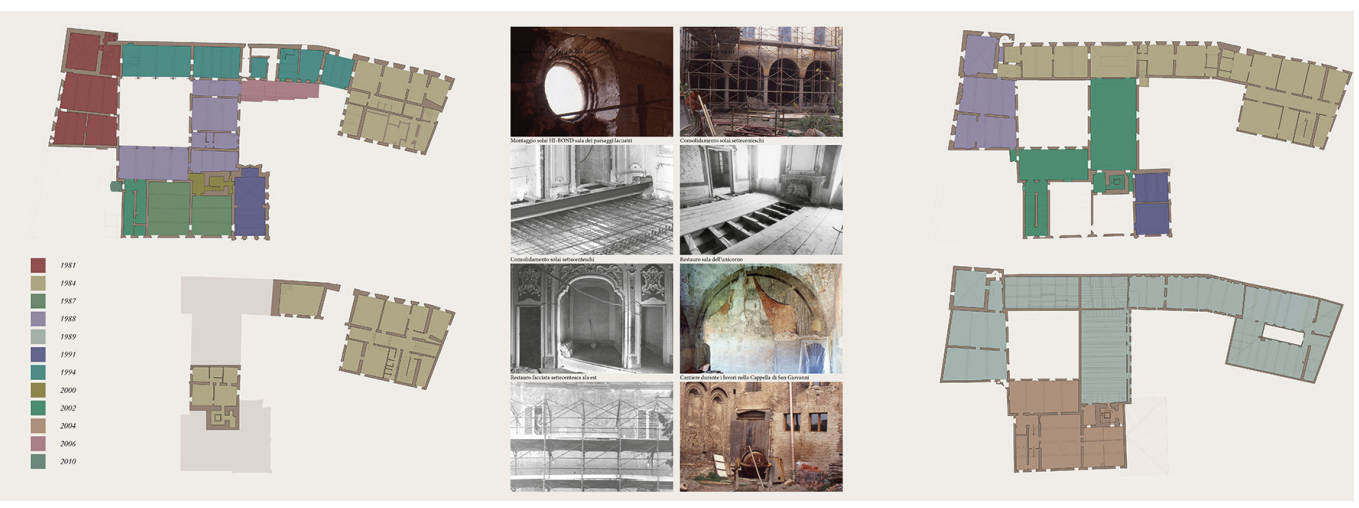

\section{L'archivio lavori dello studio d'architettura Severi}

L'architetto Mauro Severi inizia la sua attività di studio e analisi della Rocca nel 1972, al fine di elaborarne il restauro generale, condotto per lotti di lavori, nell'arco di circa cinquant'anni (fig. 3). L'archivio dello studio Severi, fondato nel 1976 (denominato Severi Architetti Associati, con sede a Reggio Emilia), conserva oggi un importante corpus di documentazione relativo a tutti i restauri e i consolidamenti strutturali condotti da quella data ad oggi, composto perlopiù da disegni cartacei e relazioni, organizzati nelle cartelle per lotti di intervento. Molti dei disegni sono controlucidi radex o copie eliografiche dei disegni originali e sono catalogati in un elenco cartaceo organizzato per numero di cartella, in ordine cronologico di esecuzione dei lavori. Allinterno delle cartelle si trovano anche schizzi, disegni di studio, appunti, integrazioni di rilievi, dime di cartone e lettere contenenti i pareri della Soprinten- 
Fig. 4. II modello HBIM dell'edificio, pensato anche quale luogo digitale di raccolta di tutti i dati d'archivio disponibili sulla Rocca.

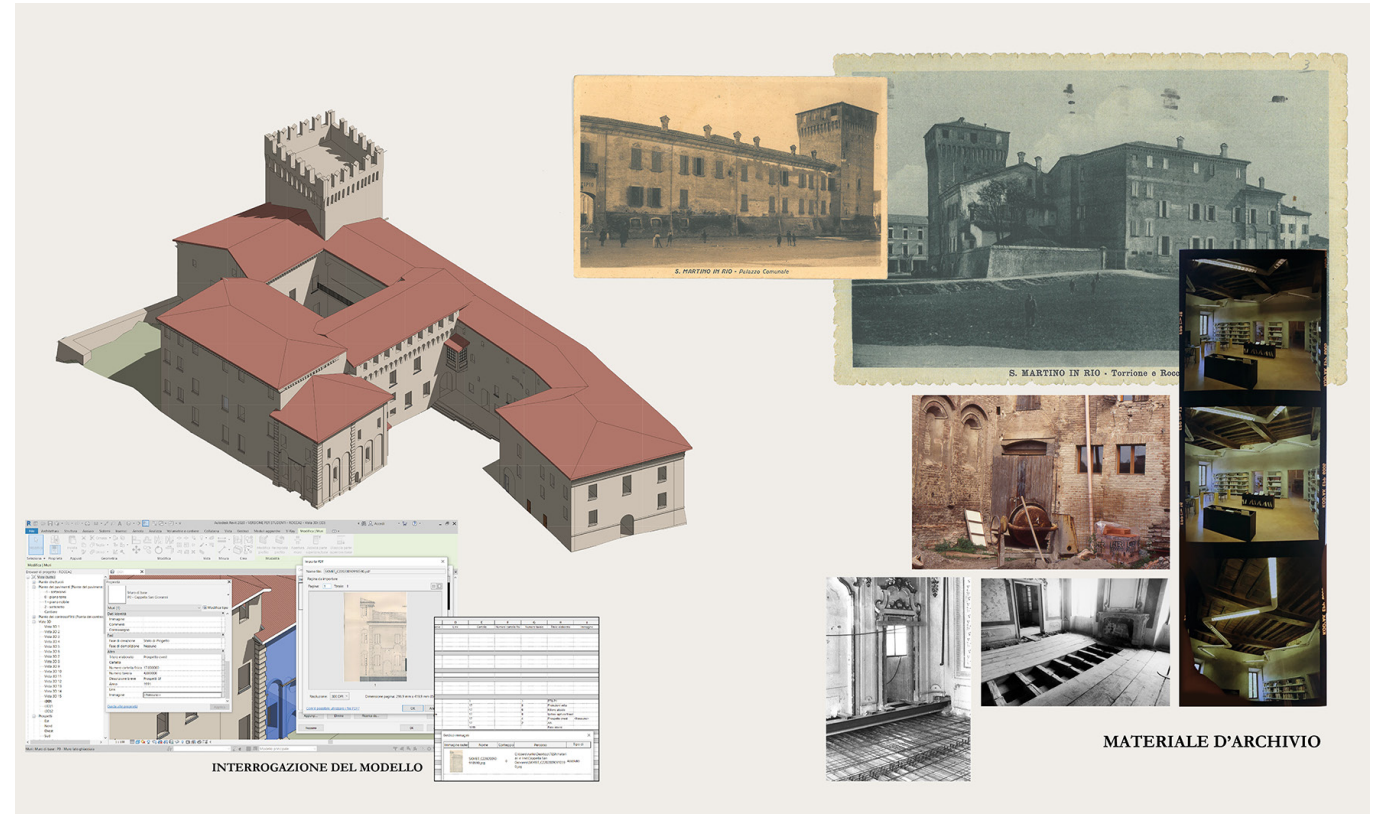

denza Archeologia, Belle Arti e Paesaggio per la città di Bologna e le province di Modena, Ferrara e Reggio Emilia. Oltre a questo materiale, lo studio conserva alcuni lucidi originali in formato A0, non catalogati all'interno dell'inventario. Pochi invece i disegni in digitale, prevalentemente scansioni o digitalizzazioni di vecchi rilievi.

Lo studio conserva poi un archivio fotografico imponente sulla Rocca, comprendente fotografie, diapositive e cartoline d'epoca, molte delle quali risalenti ai primi anni del Novecento. Lo scopo primo della ricerca è stato quello di creare un catalogo digitale di questo corpus documentario, omnicomprensivo e implementabile, a partire dall'inventario cartaceo. Data la caratteristica di molti dei disegni conservati, a grande scala di dettaglio, la sfida è stata quella di pensare ad un catalogo che potesse essere interrogabile anche a partire da un modello tridimensionale, in modo da poter accedere ai disegni tecnici di dettaglio, digitalizzati, sia dal database che dai singoli elementi costruttivi, o viceversa. In questo modo si sarebbe potuto accedere rapidamente alle informazioni relative agli interventi pregressi sui singoli elementi costruttivi, in maniera puntuale, utilizzando un software BIM ad elementi parametrici (fig. 4). Dal punto di vista dei criteri di catalogazione, si è scelto di costruire un database dei documenti inventariati (plug-in DB-Link-MS Access) che ricalcasse la struttura già utilizzata dallo studio. L'esigenza era, da un lato, di ottenere un database tridimensionale interrogabile, contenente tutti i dati relativi ai diversi interventi eseguiti negli anni sulle varie parti dell'edificio; dall'altro quello di poter mettere in relazione tra loro le informazioni sui singoli elementi costruttivi, attraverso una serie di campi comuni nel database, che per esempio consentissero di risalire, a partire dai singoli oggetti 3D, alla campagna di lavori condotta, consentendo la visualizzazione degli altri elementi oggetto dello stesso lotto. Metodologicamente, in questo

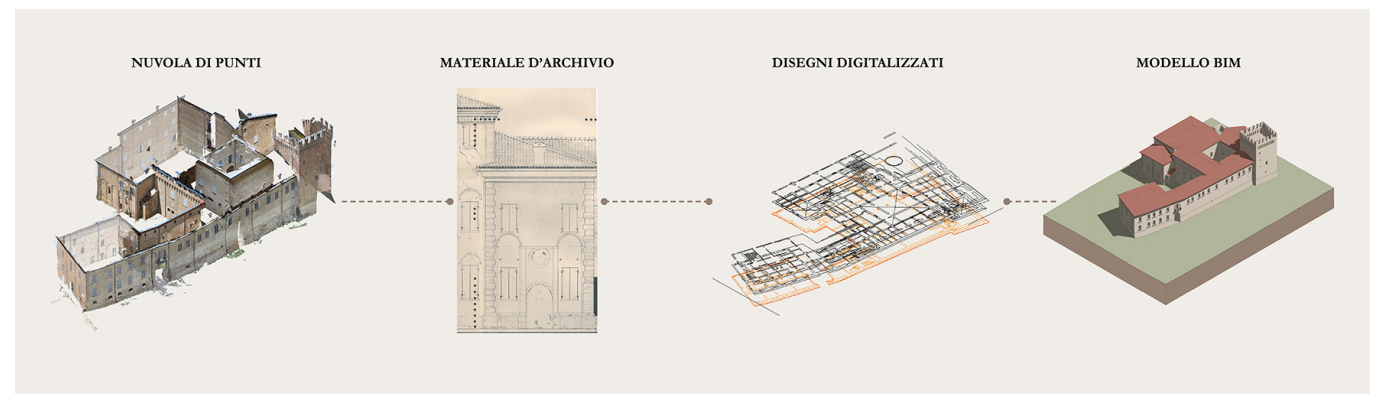

Fig. 5. Schema del dei dati disponibili (documenti d'archivio, rilievi cartacei e digitali) e di quelli di nuova acquisizione (dati fotogrammetrici tridimensionali), al fine $d_{i}$ creare un modello HBIM dell'intero edificio. 
modo, si è ottenuto un certo grado di interoperabilità dei dati d'archivio, tra loro e con il modello 3D generato, implementabile in futuro.

Tale banca dati è stata pensata per poter in futuro essere collegata al Sigec del ICCD o ad altri cataloghi dei Beni Culturali (es. Regione Emilia Romagna), al momento solo aggiungendo un campo comune contenente l'ID dell'edificio.

\section{Dai rilievi alla costruzione di un database e di un modello tridimensionale BIM per la gestione dell'archivio Severi}

II modello BIM per elementi costruttivi così costruito, rappresenta un importante strumento di supporto alle attività di conservazione, gestione e manutenzione del bene nel tempo, consentendo di accedere, in maniera rapida e puntuale, a tutti i dati relativi ai singoli elementi restaurati.

Data la grande quantità di disegni, rilievi e documenti d'archivio disponibili, per creare il modello sono stati impiegati i disegni di rilievi eseguiti dal 1969-70 al 20|4, geo-referenziandoli in un unico sistema di riferimento, a partire da un inquadramento topografico recente (figg. 5-6). In questo modo le basi 2D create sono state importate in Autodesk Revit e sono servite come riferimento per la costruzione del modello HBIM dell'edificio.

Per quanto riguarda il disegno dei fronti, la scelta è ricaduta sull'uso della fotogrammetria digitale tridimensionale: le foto per la creazione delle orto-foto dei fronti esterni in scala 1:50 sono state acquisite con una camera fotografica single-lens reflex Nikon D3500 (6000 $\times 4000$ pixel) e obiettivo da $35 \mathrm{~mm}$. Con il software Agisoft PhotoScan, oltre alle orto-foto, sono state esportate le nuvole di punti ottenute (formato *.e57), successivamente importate in Revit per le operazioni di modellazione parametrica (fig. 7). II disegno delle sezioni interne e dei dettagli costruttivi parametrici in 3D è avvenuto partendo dai disegni disponibili in archivio (figg. 8, 9).
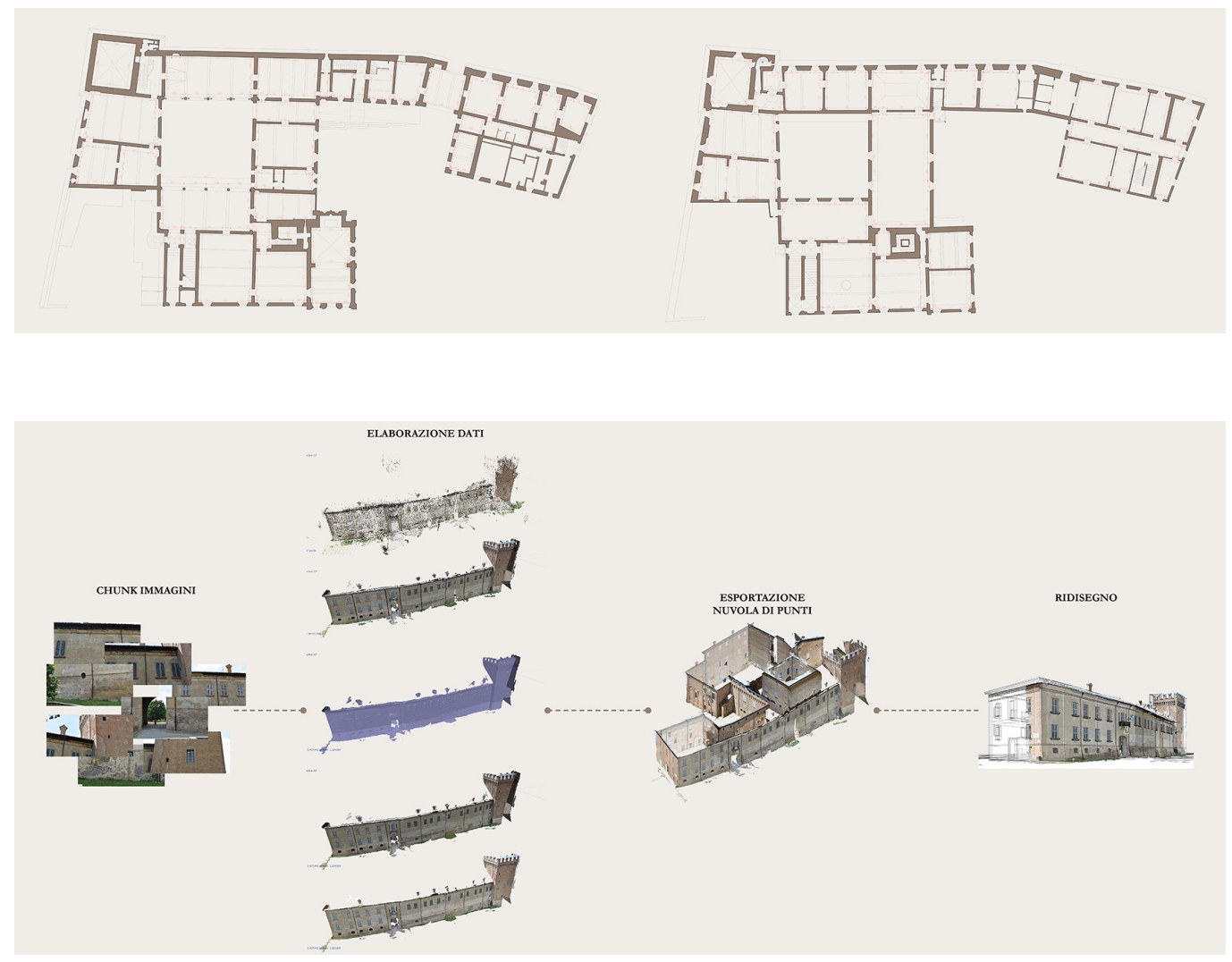
Fig. 8. Prospetti nord ed est della Rocca, con ortofoto in scala 1:50.
Fig. 9. Sezioni trasversal della Rocca, con ortofoto in scala |:50.
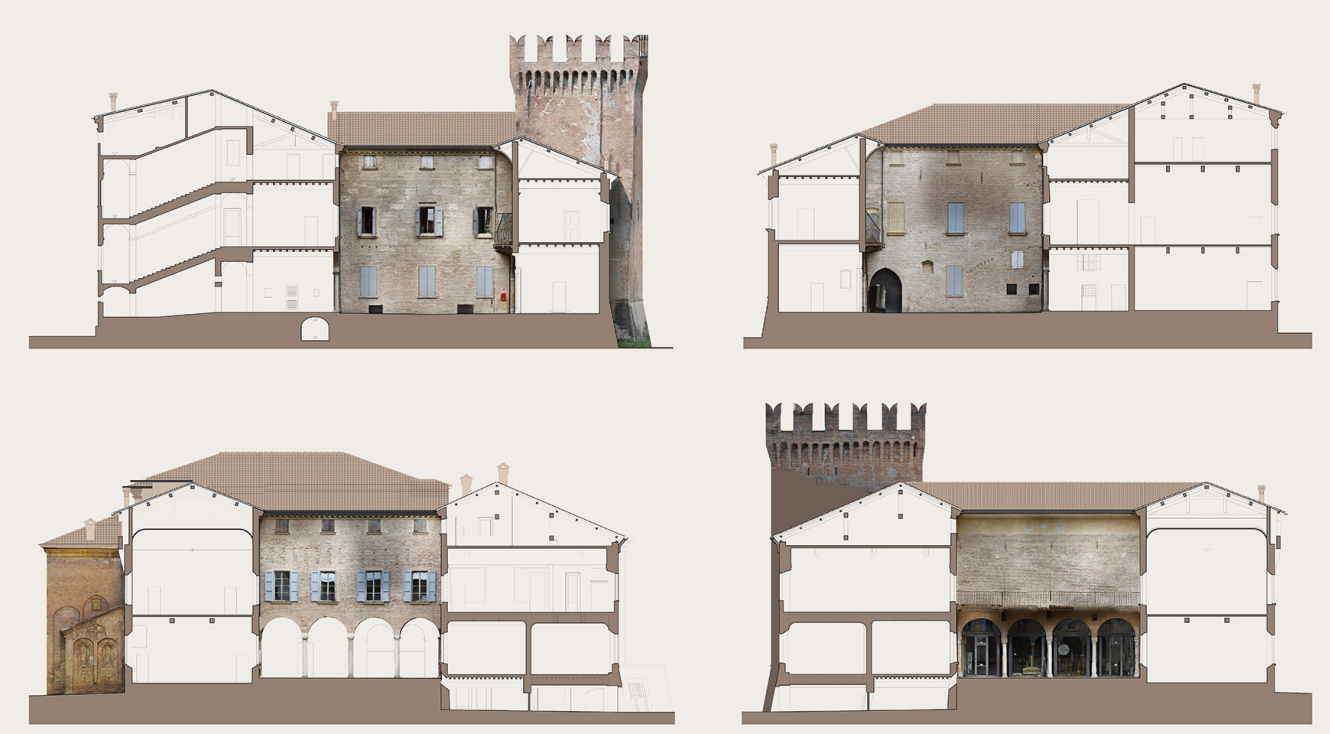
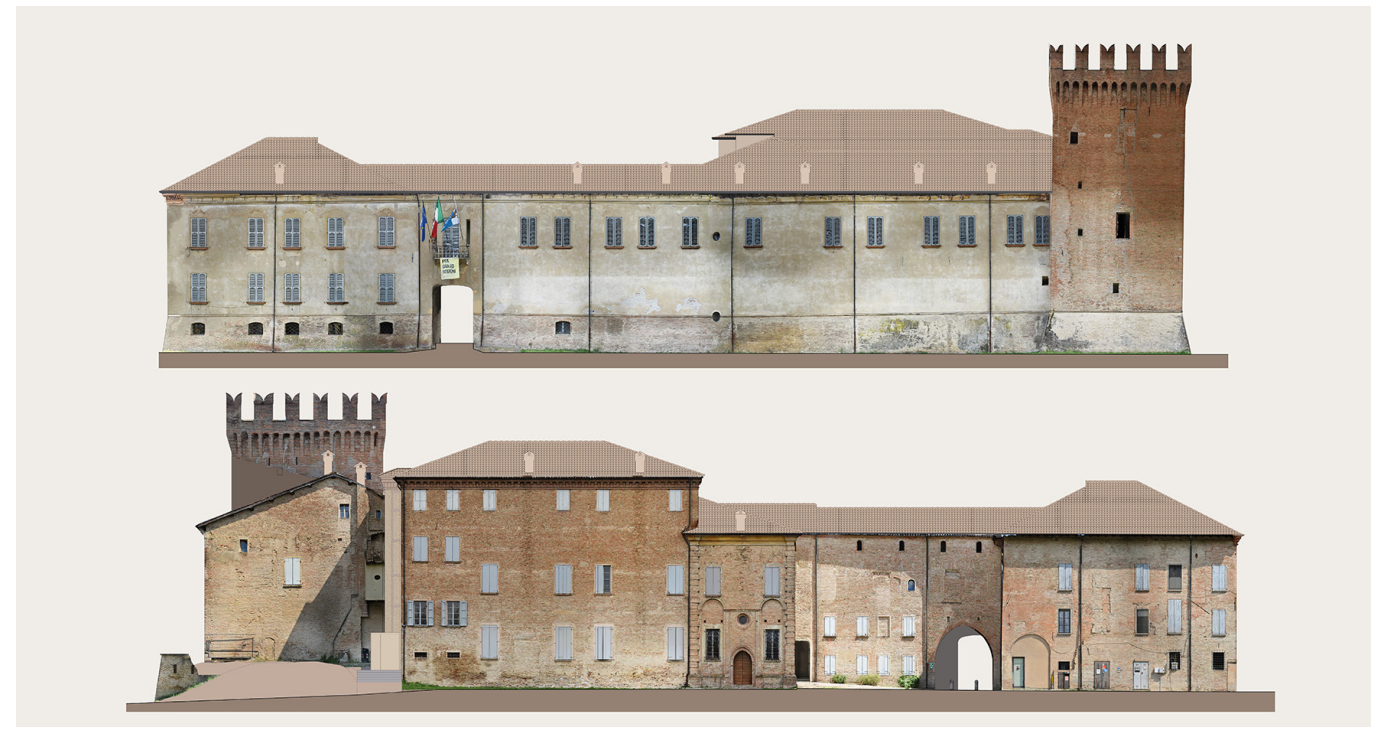

\section{La definizione dell'abaco degli elementi costruttivi del modello HBIM}

La progettazione del modello tridimensionale è stata fatta tenendo conto della necessità di poter semplificare o approfondire alcune parti in funzione del livello di dettaglio delle informazioni (Level Of Information - LOI) di restauro disponibili sui singoli elementi costruttivi (fig. I0). Ciò ha significato ragionare sul diverso livello di rappresentazione geometrica dei diversi elementi del modello (Level of Geometry - LOG), e sulle modalità di suddivisione e organizzazione degli elementi costruttivi da modellare. Facendo riferimento alla norma UNI I | 337-4:20 I 7 e alle successive specifiche (in particolare la UNI EN I 74 I2- |:202 I), era comunque indispensabile un livello di dettaglio compatibile con un livello di sviluppo degli elementi modellati (Level Of Development - LOD) E o F, come previsto per i progetti di restauro (As Built).

La complessità geometrico-morfologica degli elementi storici e degli ambienti che caratterizzano la Rocca (es. solai lignei, volte, elementi decorativi, serramenti, ecc.) ha reso in alcuni casi necessario utilizzare software di modellazione pura (quali Rhinoceros) per definirne l'esatta forma ed evitare semplificazioni che non ne sapessero restituire la ricchezza o la 
stratificazione. In questo senso, il passaggio dalle nurbs all'oggetto parametrico, secondo un processo scan-to bim ormai consolidato [Banfi 20 I 6], ha consentito di ottenere un modello $\mathrm{BIM}$ con una precisione vicina a quella del valore della tolleranza di una scala di rappresentazione $1: 100$.

Non essendo sempre disponibili nelle librerie di Revit gli elementi necessari, in molti casi sono stati utilizzati anche i comandi base di modellazione, adattandoli alle situazioni reali.

Fig. 10. Esempio di interrogazione de database a partire dall'oggetto BIM parametrico.

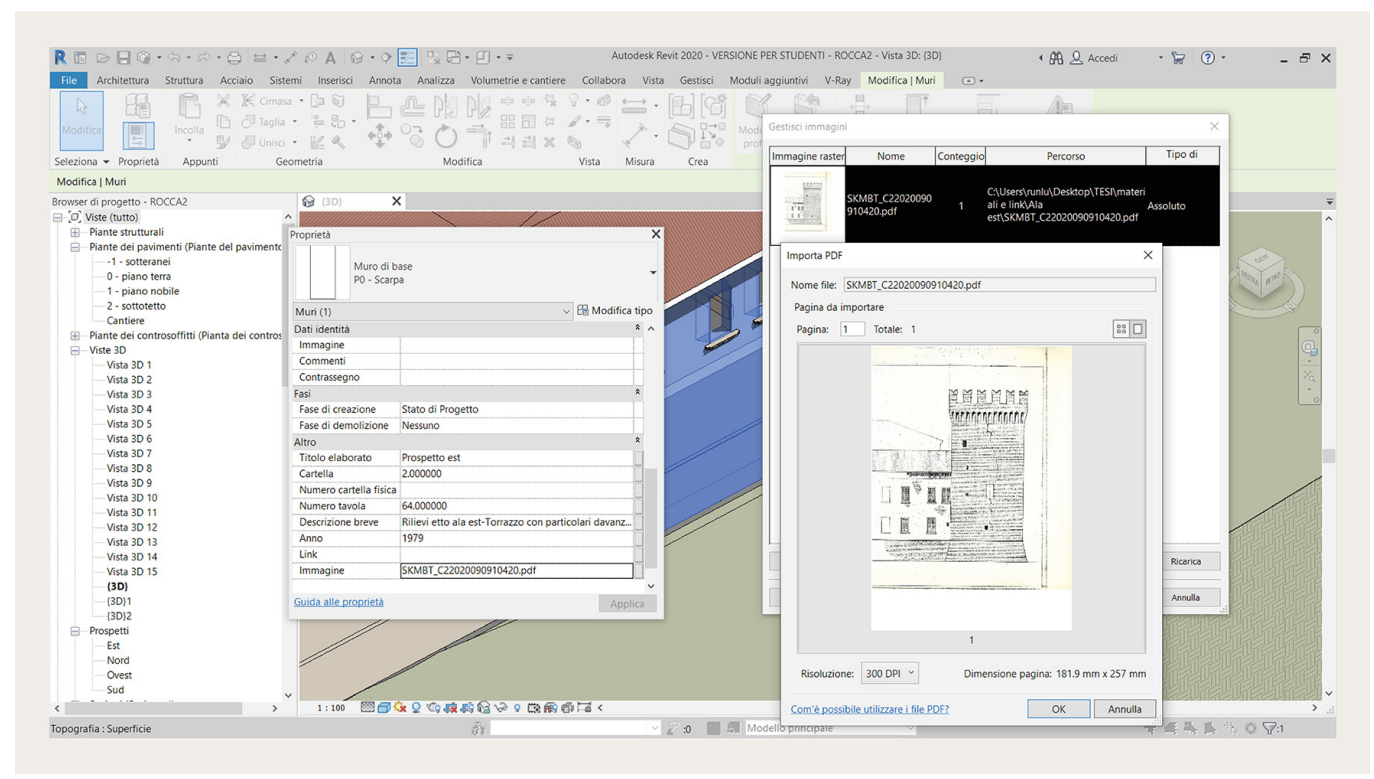

\section{Conclusioni}

Questo lavoro di ricerca ha mostrato quanto la modellazione 3D per elementi possa essere utile anche per la gestione dei dati riguardanti gli interventi passati di restauro degli edifici storici, fondamentali per la conservazione e manutenzione del bene nel tempo, oltre che per la gestione delle fasi di progettazione e cantiere. Alla grande mole di studi, analisi, ricerche e rilievi condotti negli edifici storici negli anni, non corrisponde purtroppo sempre una altrettanta facilità di reperimento degli stessi. Nonostante già la Carta di Venezia del 1964 auspicasse la necessità di condivisione e pubblicazione dei dati di cantiere e di documentazione degli edifici storici interessati da attività di restauro, per diversi motivi, non ultimi quelli legati alla proprietà intellettuale delle informazioni, è ancora troppo spesso difficile reperire in maniera agevole tali dati. Si tratta di un tema complesso, che rimanda anche alla questione generale e più ampia della digitalizzazione (Dichiarazione UNESCO/UBC di Vancouver del 20/2) e messa in rete degli archivi, pubblici e privati, ma che sicuramente richiede una riflessione anche rispetto alla possibilità dei nuovi strumenti informatici di supportare l'organizzazione e la gestione di una grande mole di dati, spesso eterogenei.

Fatte le dovute distinzioni, un modello BIM consente oggi di catalogare, in tre dimensioni, dati di diversa natura, così come ormai è prassi normale per la gestione di dati 2D nei GIS, strumenti poco efficaci per rappresentare e contenere la complessità dell'architettura, per sua natura tridimensionale. La creazione di un modello 3D capace di divenire contenitore di tale complessità morfologica, formale e di contenuti, richiede una serie di riflessioni sulle caratteristiche di un modello geometrico per elementi, sul suo livello di accuratezza geometrica (LOG), in relazione alla scala di rappresentazione e alla possibilità reale di essere semplificato o scomposto ulteriormente, al fine di collegare di volta in volta le informazioni disponibili (LOI). Se questo da un lato non costituisce un problema di rilievo, vista l'ampia gamma di tecnologie disponibili, anche low cost, pone invece un quesito in termini di scelta delle caratteristiche del modello geometrico. Al momento non esistono infatti delle linee 
Fig. I I. Mappatura dell attuale stato di degrado del fronti; a destra, per confronto, tre immagini del front principale, nel 1909, 1977,1990 (dall'alto in basso). guida o delle indicazioni normative che definiscano le caratteristiche di un modello 3D a seconda del LOG impiegato; ciò che si è pertanto fatto in questo lavoro di ricerca è stato utilizzare la tolleranza della scala di rappresentazione I: I00, che di solito si usa per le rappresentazioni 2D, anche per rappresentare i diversi elementi architettonici tridimensionali. La convinzione generale che ha guidato questo lavoro di ricerca è che i costi per la realizzazione di un catalogo tridimensionale digitale di un edificio storico si possano tradurre in un risparmio in fase di progettazione e gestione dei futuri cantieri di restauro, non disperdendo conoscenza ma arricchendola ogni volta (fig. II).

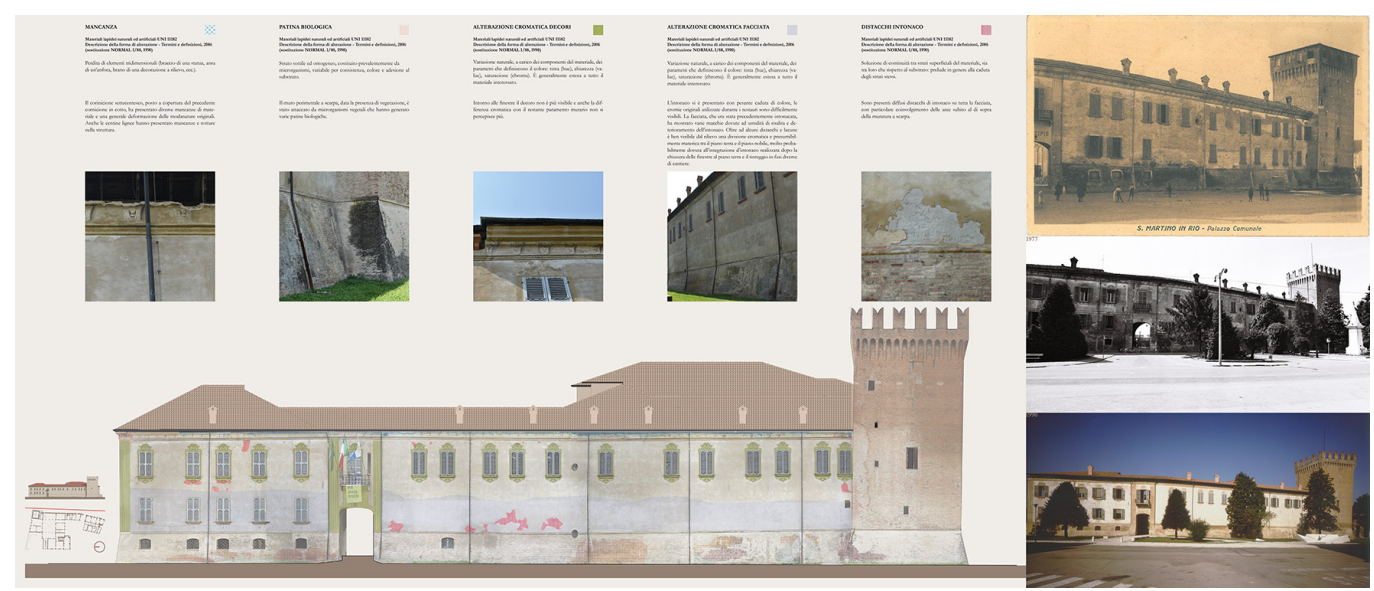

\section{Riferimenti bibliografici}

AA.W. (1976). Architettura fortificata. Piacenza e Bologna: Istituto Italiano dei Castelli.

Banfi F. (20 I7). BIM orientation: grades of generation an infor-mation for different type of analysis, and management process. In The International Archives of Photogrammetry, Remote Sensing and Spatial Information Sciences, vol. XLII-2M5.

BaricchiW. (1985). Insediamento storico e beni culturali Comune di Reggio Emilia. Reggio Emilia: IBC.

Bellocchi U. (1984). San Martino in Rio Vicende e Protagonisti. Reggio Emilia:Tecnostampa.

Cottafavi C. (2019). San Martino in Rio. Ricerche storiche. Reggio Emilia: Atesa. Edizione originale 1885.

López F. J. et. al. (20 I 8). Linking HBIM graphical and semantic information through the Getty AAT: Practical application to the Castle ofTorrelobatón. In IOP Conference Series: Materials Science and Engineering, pp. I-8.

Lo Turco M. et. al. (20 I6). BIM e beni architettonici: verso una metodologia operativa per la conoscenza e la gestione del patrimonio culturale-BIM and architectural heritage: towards an operational methodology for the knowledge and the management of Cultural Heritage. Disegnarecon, n. 9 (16)

Oreni D. et al. (20I3). HBIM for conservation and management of built heritage:Towards a library of vaults and wooden beam floors. In ISPRS Annals, vol. II-5/WI.

Severi M. (2003). La Rocca Grande di San Martino in Rio. Reggio Emilia: Comune di San Martino in Rio.

UNESCO/UBC (20I2). UNESCO/UBC Vancouver Declaration. The memory of the world in the digital age: digitization and preservation. Vancouver: UNESCO.

\section{Autori}

Luca Masiello, Severi Architetti Associati, masielloluca@outlook.com

Daniela Oreni, Politecnico di Milano, daniela.oreni@polimi.it

Mauro Severi, Severi Architetti Associati, sevarc@tin.it

Per citare questo capitolo: Masiello Luca, Oreni Daniela, Severi Mauro (202I). Un modello HBIM per la catalogazione dei restauri e la gestione degli interventi: la Rocca estense di San Martino in Rio/A HBIM Model to Catalogue the Restorations and to Manage the Interventions: the Rocca Estense of San Martino in Rio. In Arena A. Arena M. Mediati D. Raffa P. (a cura di). Connettere. Un disegno per annodare e tessere Linguage Distanze Tecnologie. Atti del $42^{\circ}$ Convegno Internazionale dei Docenti delle Discipline della Rappresentazione/Connecting. Drawing for weaving relationship. Languages Distances Technologies. Proceedings of the 42th International Conference of Representation Disciplines Teachers. Milano: FrancoAngeli, pp. 2455-2470. 


\title{
A HBIM Model to Catalogue the Restorations and to Manage the Interventions: the Rocca Estense of San Martino in Rio
}

\author{
Luca Masiello \\ Daniela Oreni \\ Mauro Severi
}

Abstract

The studies and analyses conducted on the Rocca estense of San Martino in Rio, a small village in the province of Reggio Emilia, focused on the restoration and reuse interventions carried out on the building from the 1970s to the present day by the Severi architectural studio. The purpose of the research was to explore the possibility of creating a three-dimensional BIM model of the building in which to bring together all the data, mostly paper (drawings, reports, metric calculations, etc.), within a single three-dimensional digital environment, so as to be able to query bilaterally the database works from the model or information organized into fields. Therefore, it was necessary to proceed with an exploration of the existing paper archives, inventoried, and then organize the data and digitize the existing documents. This phase was also fundamental in order to decide how to represent and divide the 3D model of the building into its various architectural elements, so as to be able to associate, in the most direct way possible, all the available information related to the different conservation, consolidation and restoration interventions that took place over time.

The final aim of this research was to create a digital tool that could serve for the future conservation activities of the building and for the management of planned maintenance activities, an open and implementable tool.

Keywords

cataloguing, archive, survey, conservation, HBIM.

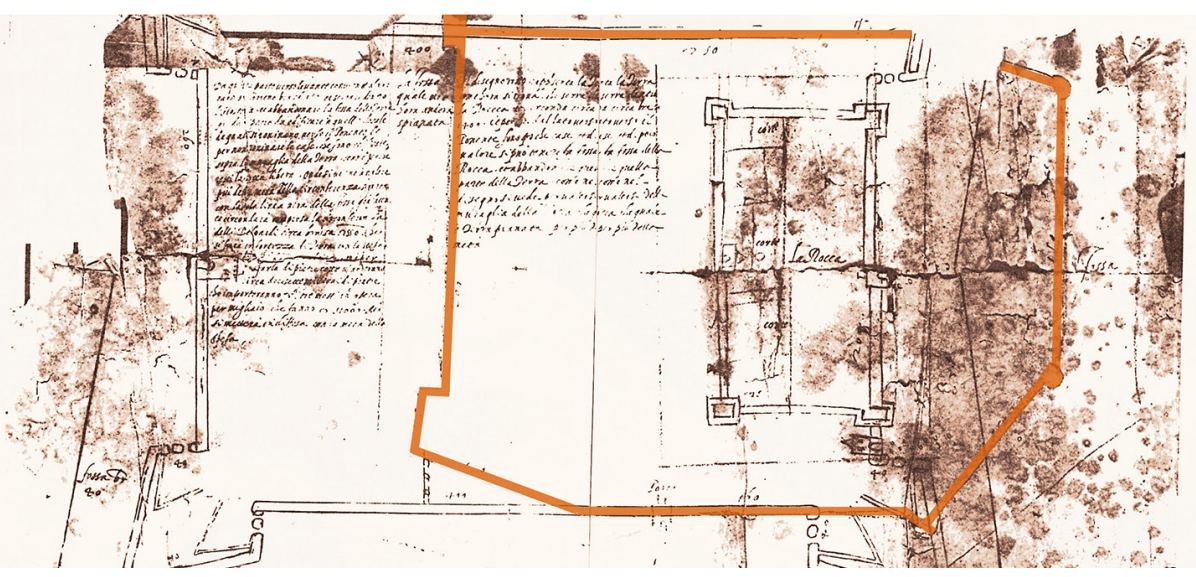




\section{The Rocca of San Martino in Rio in history: transformation and restoration}

The oldest evidence of the existence of a fortified building in this place dates back to the year 1000 [Severi 2003] (fig. I). In the list of castles and parishes received as a feud by Bonifacio di Canossa (985- I052) from the bishops of Reggio Emilia, the Castellum Sancti Martini in Rio is mentioned. In I I I5, the defensive system of San Martino grew in importance and it was enfeoffed to the Roberti family.

After 1343, the building is fortified again, becoming the defensive pivot of the territory in the fights for the creation of the Emilian Seigniories. When the Roberti family passed from the alliance with the Gonzagas to the one with the Viscontis, the Fortress was devastated and rebuilt in 1353 .

In 1442, after the consolidation of the Estense Seigniory, Leonello d'Este, Lord of Ferrara, Reggio and Modena, donates to his brother Borso the fief of San Martino in Rio and Campogalliano as a personal property. Borso begins works of accommodation of the fortress, to adapt it to his residence: in addition to a general restructuring is restored the north wing and built a porch with marble columns in the east wing. The building is the subject of a program of decoration by the painters of the Modenese family of Erri. The various enterprises of Borso found during the restorations belong to this period of interventions. In 1490 the centre of San Martino was given as a feud or autonomous Seigniory to Sigismondo d'Este, Borso's brother, and thus began the Seigniory of the Este family known as the San Martino family, a cadet branch of the family that died out in 1752.

In 1557 the Fortress was besieged and conquered again and the walls and the fortified parts of the building were damaged.

It was Filippo d'Este, the new Lord and Marquis, who, on the occasion of his marriage to Maria, daughter of Emanuele Filiberto of Savoy, intervened with important works of enlargement and internal arrangement, starting from 1570, with the addition of new rooms, of the staircase in the west wing, and with the creation of new decorative apparatus. These works are attributed to the architect Giovan Battista Aleotti.

An important campaign of restoration of the Rocca was carried out again in 1772, at the behest of the new feudal lord, Don Paolo Rango d'Aragona; the entire building was adapted in its spaces and decorations to the taste of the time. A hall is transformed into a theatre, the rooms are decorated with stucco, scagliola and marble fireplaces, the wooden ceilings of the sixteenth century are repainted or covered with canopies. In the facade of the east wing new windows are opened while the main facade is decorated by the Modenese painter Bosellini. Since 1813 the Rocca is purchased by the Community and transformed to house offices, warehouses and private residences. The tampering and incongruous uses continued.
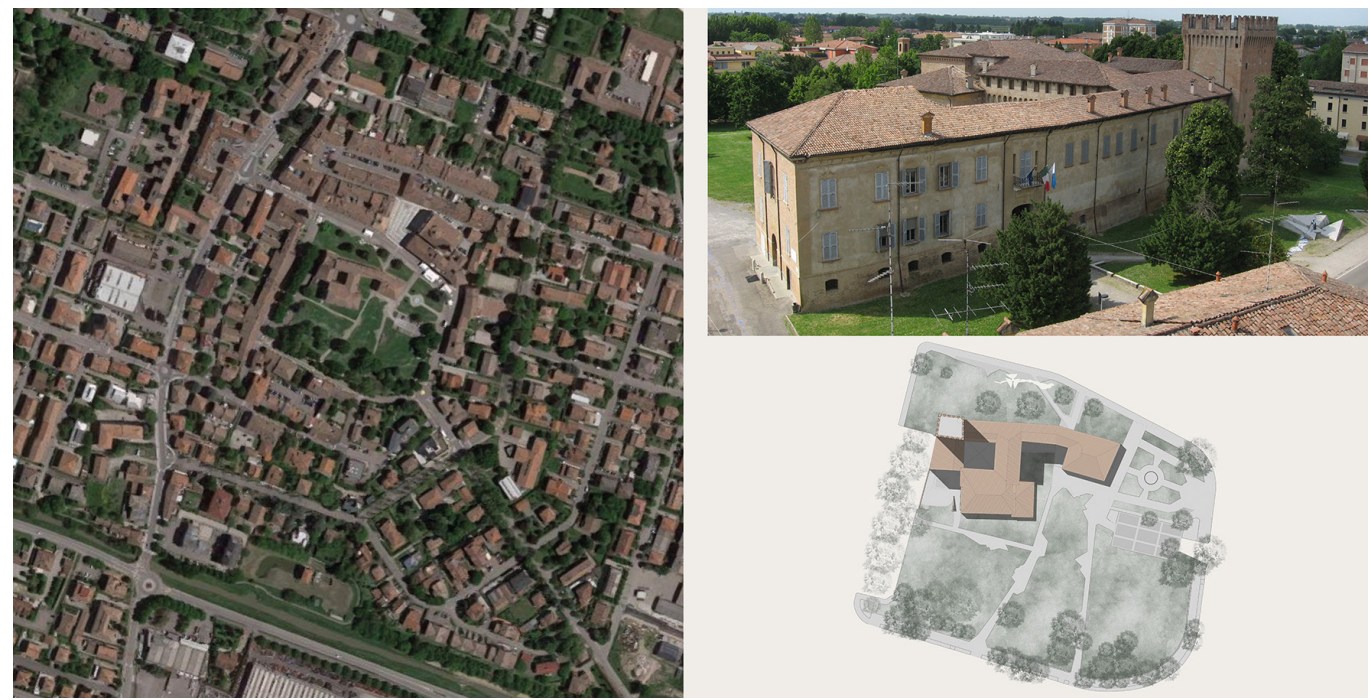
ig. 2. At the top, the coats of arms of the of the Rocca ovners centuries; at the bottom centuries, at the bottom, some significant images elements referable to the works carried out by the various owners.

Fig. 3. The different colours indicate the various lots of restoration work carried out on the building by the Severi studio, from the 1970s to the present day.

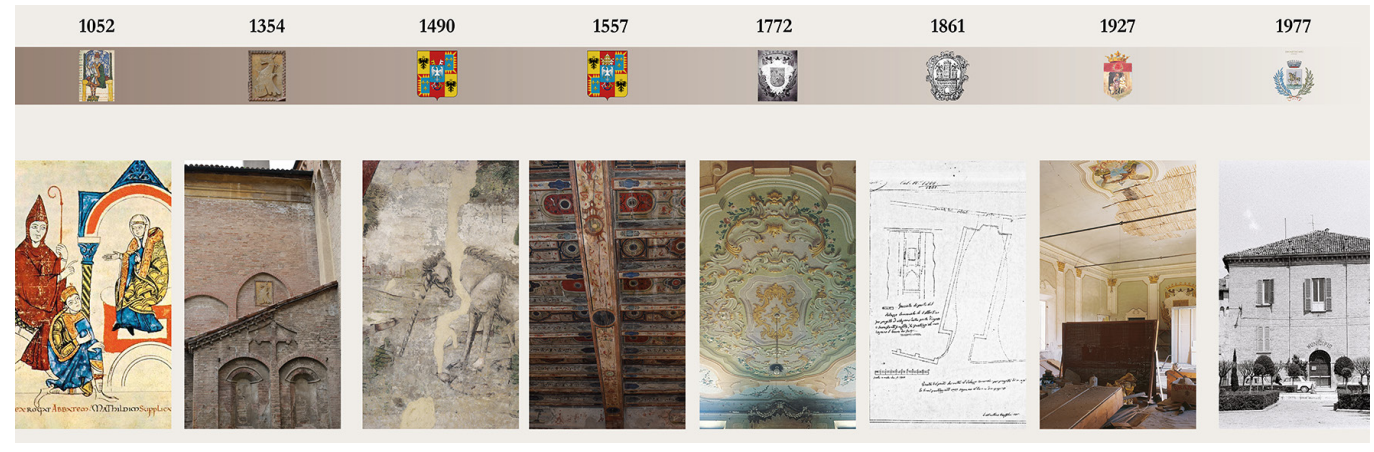

In 1927 the painted ceilings with bands and grotesques of the two rooms above the eastern portico were found. After two years, the covering of the Torrazzo is removed in the intent of an improbable medieval restoration.

In 1972 the surveys of the entire building began and, in 1977, the municipality approved the general project for the restoration and recovery of the Rocca Estense, drawn up by the architects Mauro Severi and Gianfranco Varini (fig. 2); in the same year, the consolidation and revision of the roof of the chapel of San Giovanni were also authorized.

The restoration work began in 1980 with the consolidation of the foundations of the north wing, continuing with the restoration and arrangement of the main floor of the east wing, of the wing between the two courtyards, and of the $18^{\text {th }}$ century terracotta floors on the main floor of the east wing. In 1987 the restoration of the east façade began, followed by that of the chapel of San Giovanni. In 1994 the agricultural museum was reopened. Since 1997, restoration and consolidation works have been carried out on the roofs, the attics and the wooden floors, following the damages caused by the earthquake.

The last interventions concern the repairs of the damages caused by the earthquake of 2012 .

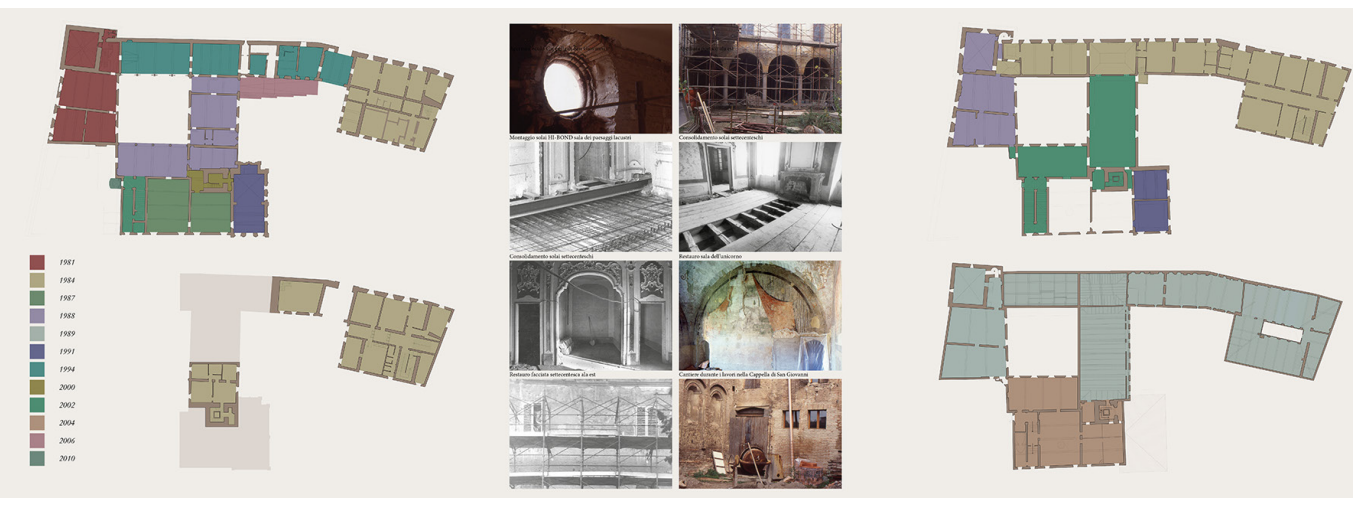

The work archives of the Severi architectural studio

Architect Mauro Severi began his activity of study and analysis of the Rocca in 1972, in order to elaborate its general restoration, conducted in lots of works over a period of about fifty years (fig. 3). The archives of the Severi studio, founded in 1976 (called Severi Architetti Associati, with headquarters in Reggio Emilia), today preserves an important corpus of documentation regarding all the restorations and structural consolidations carried out from that date to the present day, mostly composed of paper drawings and reports, organized in folders according to lots of work. Many of the drawings are radex controls or heliographic copies of the original drawings and are catalogued in a paper list organized by folder number, in chronological order of execution of the work. Inside the folders there are also sketches, 
Fig. 4. The HBIM model of the building, conceived also as a digital place of collection of all the archival data available on the Rocca.

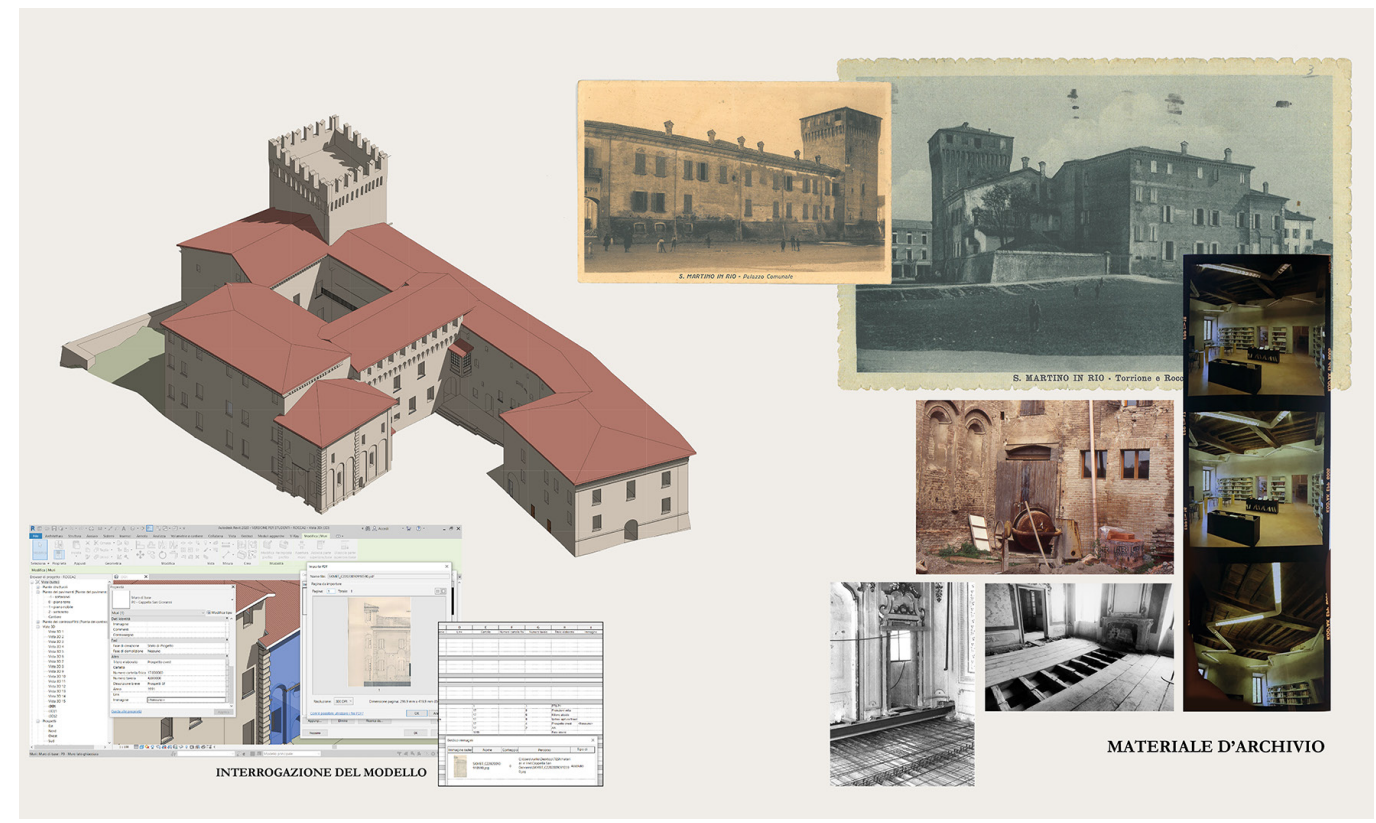

study drawings, notes, integrations of reliefs, cardboard templates and letters containing the opinions of the Soprintendenza Archeologia, Belle Arti e Paesaggio for the city of Bologna and the provinces of Modena, Ferrara and Reggio Emilia. In addition to this material, the studio conserves some original transparencies in $\mathrm{A} 0$ format, not catalogued in the inventory. There are few digital drawings, mainly scans or digitalization of old surveys.

The studio also conserves an impressive photographic archive of the Rocca, including photographs, slides and vintage postcards, many of which date back to the early $20^{\text {th }}$ century. The first aim of the research was to create a digital catalogue of this documentary corpus, all-inclusive and implementable, starting from the paper inventory. Given the characteristic of many of the drawings preserved, at a large scale of detail, the challenge was to think of a catalogue that could also be queried from a three-dimensional model, so as to be able to access the detailed technical drawings, digitized, both from the database and from the individual building elements, or vice versa. In this way, it would have been possible to quickly access information regarding previous interventions on individual building elements, in a punctual manner, using BIM software with parametric elements (fig. 4).

From the point of view of cataloguing criteria, it was decided to build a database of the inventoried documents (DB-Link-MS Access plug-in) that would follow the structure already used by the study. The need was, on the one hand, to obtain a three-dimensional database that could be queried, containing all the data relative to the various interventions carried out over the years on the different parts of the building; on the other hand, to be able to relate the information on the individual construction elements, through a series of common fields in the database, that would allow, for example, to trace back, starting from the indi-

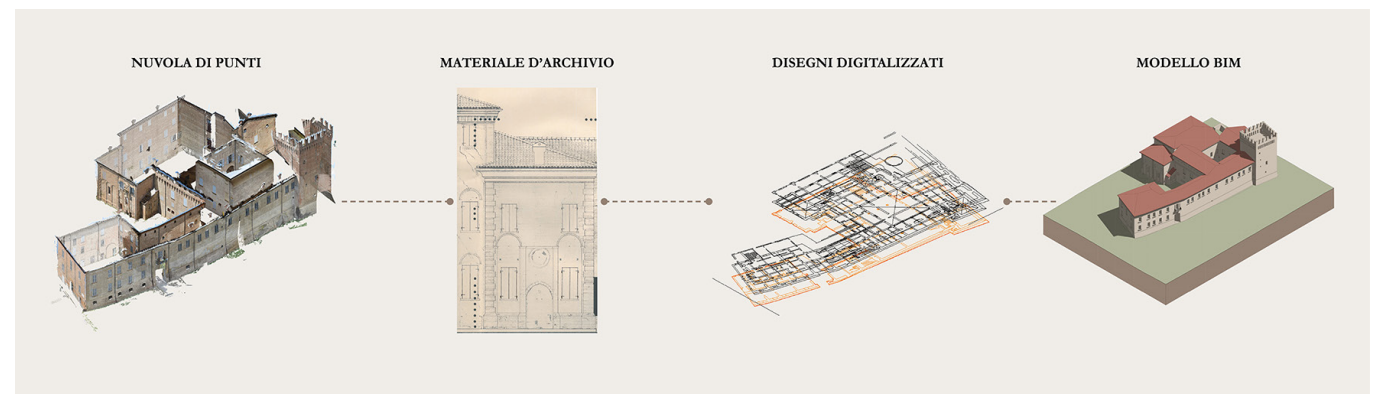

Fig. 5. Scheme of the elaboration process of the available dat (archival documents, paper and digital surveys) and of the surveys) and of the newly acquired data photogrammetric data) in order to create a HBIM model of the entire building. 
vidual 3D objects, the campaign of works carried out, allowing the visualization of the other elements of the same lot. Methodologically, in this way, a certain degree of interoperability of the archival data was obtained, among themselves and with the generated 3D model, implementable in the future.

This database has been conceived to be connected in the future to the Sigec of the ICCD or to other catalogues of Cultural Heritage (e.g. Regione Emilia Romagna), at the moment only by adding a common field containing the ID of the building.

\section{From surveys to the construction of a database and a BIM three-dimensional model for the management of the Severi archives}

The BIM model for building elements built in this way, represents an important tool to support the activities of conservation, management and maintenance of the asset over time, allowing access, in a quick and timely manner, to all data related to individual elements restored. Given the large amount of drawings, surveys and archival documents available, to create the model, drawings of surveys performed from 1969-70 to 20I4 were used, geo-referencing them in a single reference system, starting from a recent topographic frame (figs. 5, 6). In this way, the created 2D bases were imported into Autodesk Revit, and served as a reference for the construction of the HBIM model of the building.

As for the design of the fronts, the choice fell on the use of three-dimensional digital photogrammetry: the photos for the creation of ortho-photos of the external fronts in scale 1:50 were acquired with a single-lens reflex Nikon D3500 camera $(6000 \times 4000$ pixels) and 35mm lens. Using Agisoft Photo Scan software, in addition to the ortho-photos, the point clouds obtained were exported (*.e57 format), which were subsequently imported into Revit for parametric modelling operations (fig. 7). The design of the internal sections and parametric construction details in 3D was done starting from the drawings available in the archive (figs. 8,9).
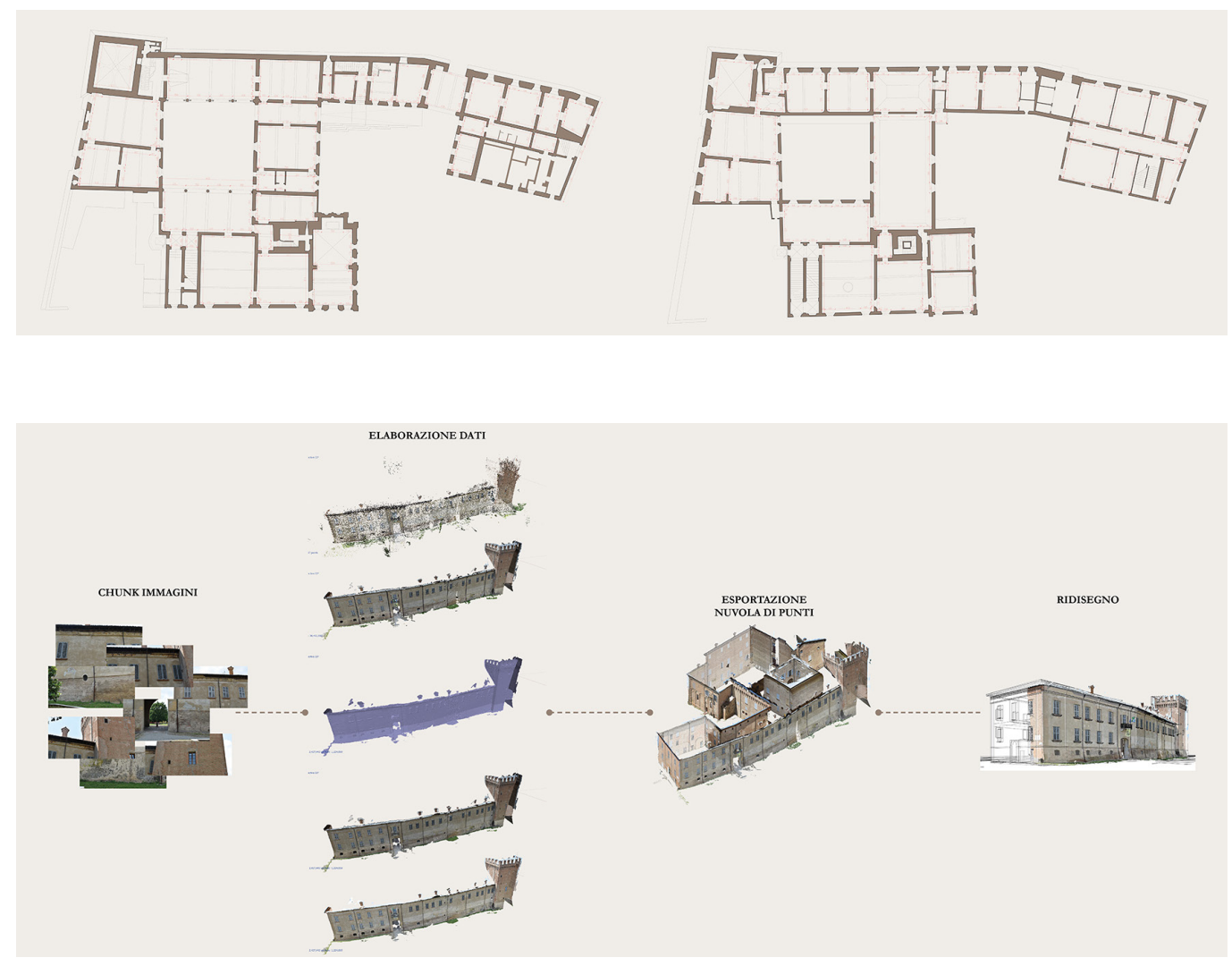
Fig. 8. North and east views of the Rocca, with ortho-photos in scale 1.50.
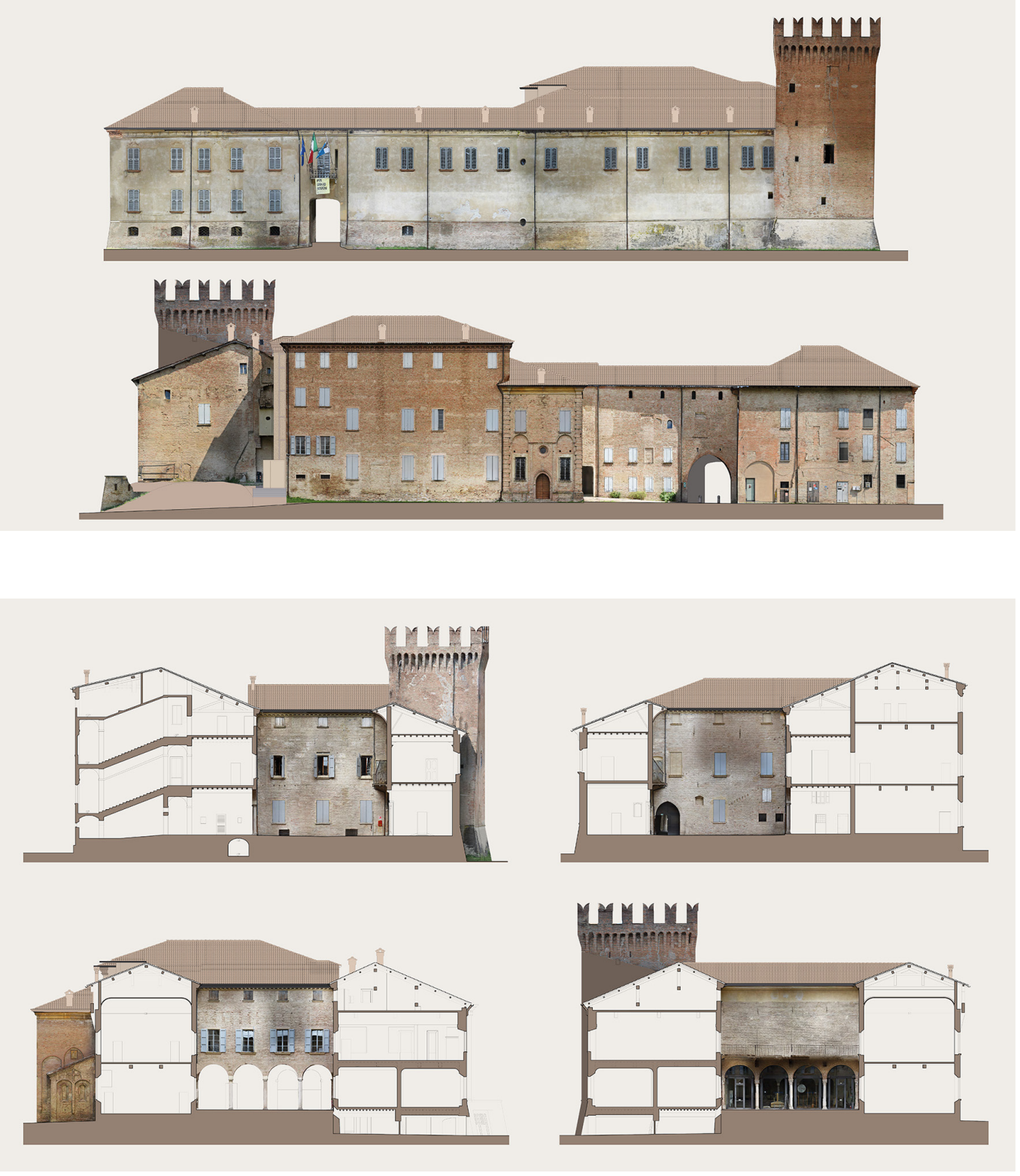

The definition of the abacus of the constructive elements of the HBIM model

The planning of the three-dimensional model has been made keeping in mind the necessity to be able to simplify or to deepen some parts, in function of the level of detail of the information (Level Of Information - LOI) of restoration available on the single constructive elements (fig. I0). This has meant to reason on the different level of geometric representation of the different elements of the model (Level of Geometry - LOG), and on the modalities of subdivision and organization of the constructive elements to model. Referring to the UNI | |337-4:20 I7 standard and subsequent specifications (in particular UNI EN I74 I2-1:2021), it was however essential to have a level of detail compatible with a level of development of the modelled elements (Level Of Development - LOD) E or F, as expected for restoration projects (As Built).

The geometric-morphological complexity of the historical elements and environments that characterize the Rocca (e.g. wooden ceilings, vaults, decorative elements, doors and windows, etc.) has made it necessary in some cases to use pure modelling software (such as Rhinoceros) to define the exact shape and avoid simplifications that could not restore 
Fig. 10. Example of database query starting object. the richness or stratification. In this sense, the transition from Nurbs to the parametric object, according to a scan-to bim process now consolidated [Banfi 20 I6], has allowed to obtain a BIM model with an accuracy close to that of the tolerance value of a representation scale 1:100.

Since the necessary elements are not always available in the Revit libraries, in many cases the basic modelling commands were also used, adapting them to real situations.

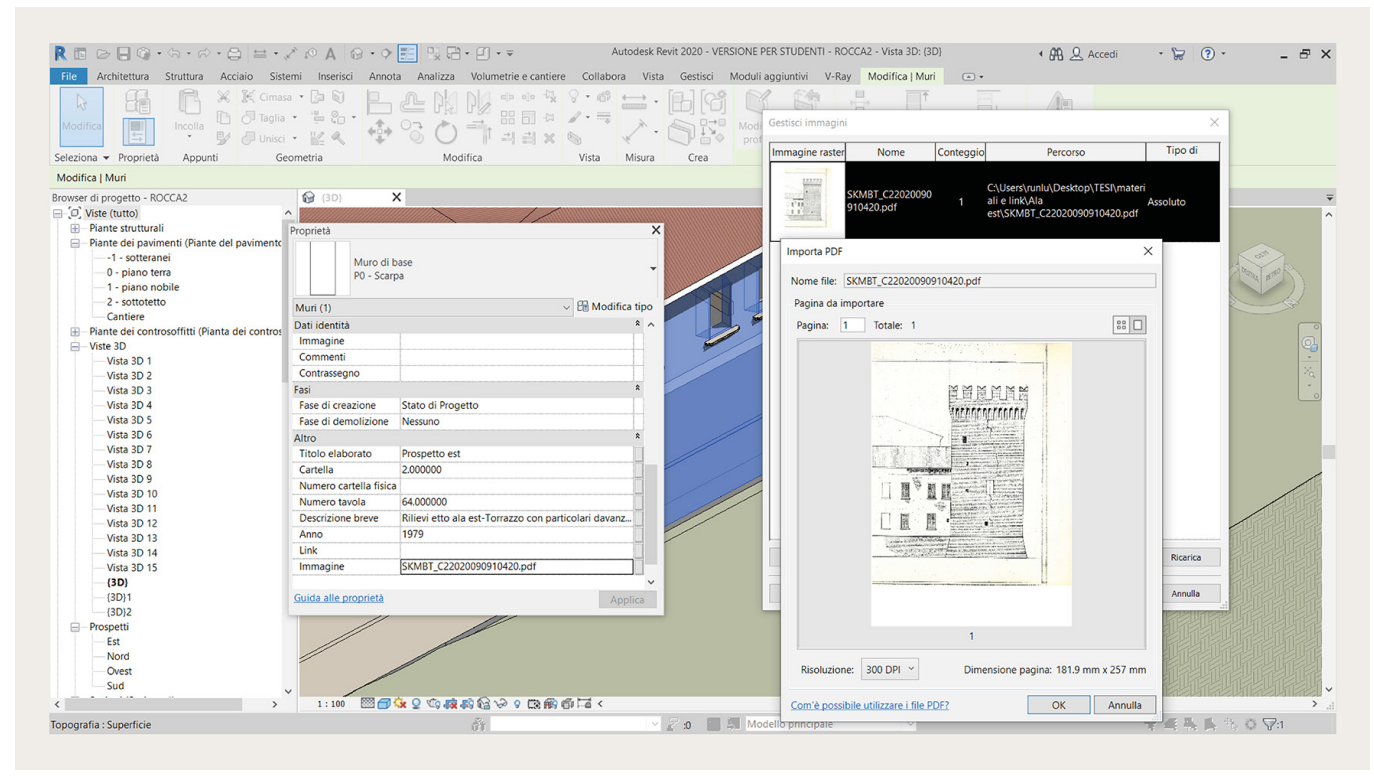

\section{Conclusions}

This research work has shown how much three-dimensional modelling for elements can be useful also for the management of data regarding past restoration of historic buildings, fundamental for the preservation and maintenance of the property over time, as well as for the management of the design and construction phases. Unfortunately, the great amount of studies, analyses, researches and surveys carried out on historical buildings over the years is not always matched by an equally easy retrieval of the same. Despite the fact that the 1964 Venice Charter already called for the sharing and publication of construction site data and documentation of historic buildings involved in restoration activities, for various reasons, not least those related to the intellectual property of the information, it is still too often difficult to find such data easily. This is a complex issue, which also refers to the general and broader question of digitization (UNESCO/UBC Vancouver Declaration of 20I2) and networking of public and private archives, but which certainly requires a reflection on the possibility of the new IT tools to support the organization and management of a large amount of data, often heterogeneous.

With due distinction, the BIM tool today allows the cataloguing, in three dimensions, of different types of data, as is now normal practice for the management of 2D data in GIS, tools that are not very effective for representing and containing the complexity of architecture, which is three-dimensional by nature. The creation of a 3D model capable of becoming a container of such morphological complexity, formal and content, requires a series of reflections on the characteristics of a geometric model for elements, on its level of geometric accuracy ( $\mathrm{LOG}$ ), in relation to the scale of representation and the real possibility of being simplified or decomposed further, in order to connect from time to time the available information (LOI). If this on one hand is not a major problem, given the wide range of technologies available, even low cost, poses a question in terms of choice of characteristics of the geometric model. At the moment there are in fact no guidelines or normative indi- 
Fig. I I. Map of the current state of degradation of the fronts; on the right, for comparison, three images of the main front, in 1909 1977,1990 (from top to bottom) cations that define the characteristics of a 3D model depending on the LOG used; what has therefore been done in this research work was to use the tolerance of the scale of representation 1:100, which is usually used for 2D representations, even to represent the different three-dimensional architectural elements.

The general conviction that guided this research work is that the costs for the realization of a three-dimensional digital catalogue of a historical building can be translated into savings in the design and management of future restoration sites, not dispersing knowledge but enriching it every time (fig. II).

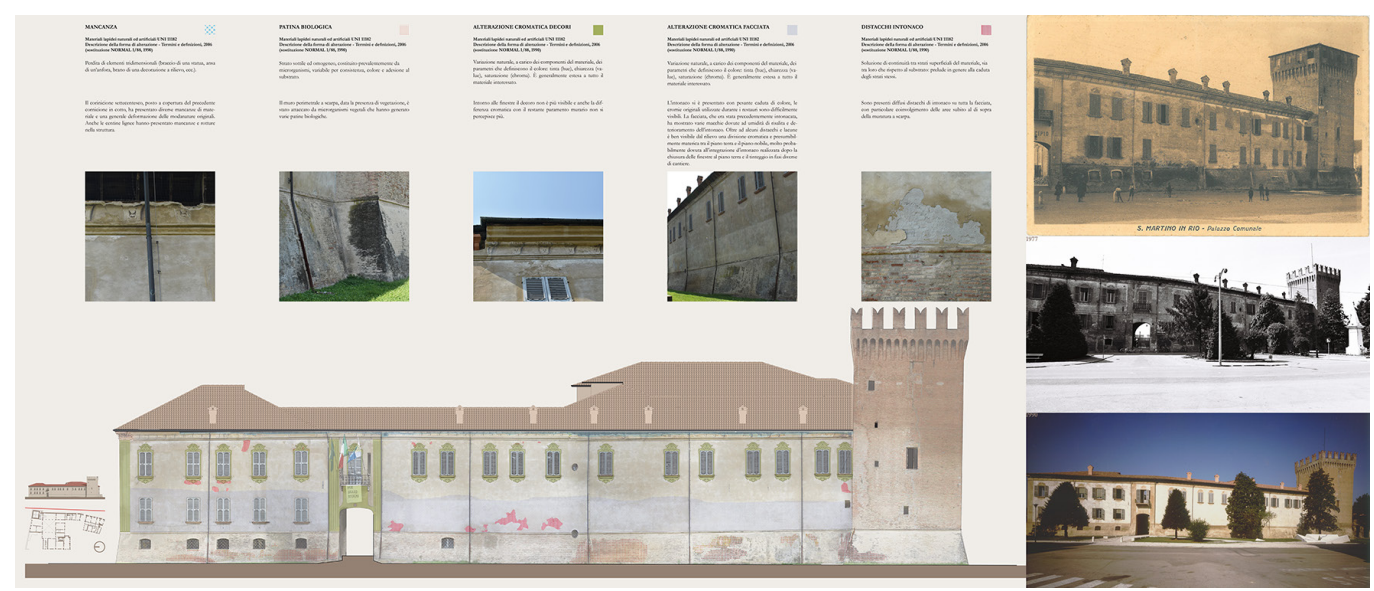

\section{Riferimenti bibliografici}

AA.V. (1976). Architettura fortificata. Piacenza e Bologna: Istituto Italiano dei Castelli.

Banfi F. (2017). BIM orientation: grades of generation an infor-mation for different type of analysis, and management process. In The International Archives of Photogrammetry, Remote Sensing and Spatial Information Sciences, vol. XLII-2/W5.

BaricchiW. (1985). Insediamento storico e beni culturali Comune di Reggio Emilia. Reggio Emilia: IBC.

Bellocchi U. (1984). San Martino in Rio Vicende e Protagonisti. Reggio Emilia:Tecnostampa.

Cottafavi C. (2019). San Martino in Rio. Ricerche storiche. Reggio Emilia:Atesa. Original edition 1885.

López F. J. et. al. (20 I 8). Linking HBIM graphical and semantic information through the Getty AAT: Practical application to the Castle ofTorrelobatón. In IOP Conference Series: Materials Science and Engineering, pp. I-8.

Lo Turco M. et. al. (20 I6). BIM e beni architettonici: verso una metodologia operativa per la conoscenza e la gestione del patrimonio culturale-BIM and architectural heritage: towards an operational methodology for the knowledge and the management of Cultural Heritage. Disegnarecon, n. 9 (16).

Oreni D. et al. (20I3). HBIM for conservation and management of built heritage:Towards a library of vaults and wooden beam floors. In ISPRS Annals, vol. II-5/WI.

Severi M. (2003). La Rocca Grande di San Martino in Rio. Reggio Emilia: Comune di San Martino in Rio.

UNESCO/UBC (20I2). UNESCO/UBC Vancouver Declaration. The memory of the world in the digital age: digitization and preservation. Vancouver: UNESCO.

\section{Authors}

Luca Masiello, Severi Architetti Associati, masielloluca@outlook.com

Daniela Oreni, Politecnico di Milano, daniela.oreni@polimi.it

Mauro Severi, Severi Architetti Associati, sevarc@tin.it

To cite this chapter. Masiello Luca, Oreni Daniela, Severi Mauro (2021). Un modello HBIM per la catalogazione dei restauri e la gestione degli interventi: la Rocca estense di San Martino in Rio/A HBIM Model to Catalogue the Restorations and to Manage the Interventions: the Rocca Estense of San Martino in Rio. In Arena A.,Arena M. Mediati D. Raffa P. (a cura di). Connettere. Un disegno per annodare e tessere. Linguagoi Distanze Tecnologie. Atti del $42^{\circ}$ Convegno Internazionale dei Docenti delle Discipline della Rappresentazione/Connecting. Drawing for weaving relationship. Languages Distances Technologies. Proceedings of the 42th International Conference of Representation Disciplines Teachers. Milano: FrancoAngeli, pp. $2455-2470$ 